\title{
Demography of helminth parasites in relation to biometic characteristics of M astacembalus armatus
}

\author{
M amta Pandey*, R. M . Saxena and Preeti Handa \\ Department of Zoology, D.A.V. (P.G.) College, Dehradun-248001 (Uttarakhand), INDIA \\ *Corresponding author. E-mail: pandey.mamta03@ gmail.com
}

\begin{abstract}
The study was conducted to collect and identify helminth parasites of Mastacembalus armatus and also to determine the prevalence intensity and abundance of parasitic infection. $118 \mathrm{M}$. armatus, obtained from different sampling stations of Yamuna river between March 2008 to February 2009 were examined for endoparasitic helminth infections. Of these only 31 fishes were found infected. Four helminth species including one nematode (Ascaridia ganpatii), two cestodes (Polyonchobothrium armatii, S enga nayari) and one trematode (Eucreadium pandeyi) were found in host fish. The over all monthly infestation of prevalence (0.29), intensity (3.28) and abundance (1.13) were recorded. The maximum infection was recorded in middle size range while very small and larger fishes showed lesser susceptibility to helminth parasites.
\end{abstract}

Keywords: Abundance, Biometic of fish, Helminth parasites, Intensity, Mastacembalus armatus, Prevalence

\section{INTRODUCTION}

Fish is a cheap and important source of protein. It contains lipids, minerals, oils and vitamins. Majority of fishes carry heavy infection of parasites, which cause deterioration in the food value of fish and may even result in their mortality. Besides, there are a number of 'helminth parasites' which are transmitted to men only through fish. Mastacembalid species are found at high altitude as well as low land in both still and running water (Woo, 1995). A wide range of parasitic infections of fresh water fishes have been studied from various parts of India. The influence of parasitic infections in relation to the length of fish has been described by Fagerholm, 1982; Zaman et al., 1986; Jha and Sinha, 1990; Tasawar et al., 2007; Ayanda, 2008; Alam et al., 2010. In recent past, the prevalence, intensity and abundance of helminth parasites in fishes have been observed by Khan et al. 2003; Singh and Malik, 2004; Ozer and Ozturk, 2004; Shomorendra et al., 2005, 2007; Singh, 2006; Akter et al., 2007 and Moyo et al., 2009 but such work is lacking on Mastacembalus armatus in the Yamuna river. So the present investigation was aimed at to study the parasitic community, prevalence, intensity and abundance of helminth parasites in $M$. armatus.

\section{MATERIALS AND METHODS}

The fish M. armatus were collected by using gill net during March 2008 to February 2009 from the Yamuna river. A total of $118 \mathrm{M}$. armatus were examined, out of which only 31 were found infected with 116 helminth parasites. The fishes were identified and grouped according to length keeping in difference of $50 \mathrm{~mm}$. Length was measured with the help of thread and scale. Trematodes and cestodes were stretched over a clean slide, fixed in alcoholic Bouin's and stained in AcetoAlum-Carmine. Nematodes were preserved in glycerin alcohol (70\% alcohol 90 part and glycerin 10 parts). They were cleaned and mounted in lactophenol without staining. Identification of the helminth parasites were done according to Yamaguti $(1959,1961,1971)$ and available references. Demography of helminth parasites were carried out using the formula given by Margolis et al. (1982)

\section{RESULTS}

During the study period total 118 fishes were examined, of these 31 fishes were found infected with helminth parasites and a total of 116 parasites were recovered. One species of nematode, Ascaridia ganpatii and two species of cestode, Polyonchobothrium armatii, Senga nayari and one trematode species Eucreadium pandeyi were found in M. armatus. Prevalence, intensity and abundance of infestation was highest in A. ganpatii (0.093, 4.9 and 0.46 respectively) and it was lowest in E. pandeyi $(0.042,2.4$ and 0.13 respectively). In case of cestodes species, hightest prevalence (0.068) was found in P. armatii and highest intensity (4.0) and abundance (0.24) was recorded in S. nayari (Table 1).

As far as monthly infestation is concerned, higher prevalence (0.56), intensity (5.8) and abundance (3.2) were observed in May. The Lowest prevalence (0.09) was recorded in July while the lowest intensity (1.0) and abundance (0.1) were observed in the month of August ISSN : 0974-9411 (Print), 2231-5209 (Online) All Rights Reserved ๑ Applied and Natural Science Foundation www.ansfoundation.org 
Table 1. Prevalance, intensity and abundance of parasites in M . armatus during the year 2008-2009.

\begin{tabular}{lccccc}
\hline Name of parasites & $\begin{array}{c}\text { No. of fish } \\
\text { infected }\end{array}$ & $\begin{array}{c}\text { No. of parasites } \\
\text { collected }\end{array}$ & Prevalence & Intensity & A bundance \\
\hline A. ganpatii & 11 & 54 & 0.093 & 4.9 & 0.46 \\
P. armatii & 8 & 22 & 0.068 & 2.8 & 0.16 \\
S. nayari & 7 & 28 & 0.059 & 4.0 & 0.24 \\
E. pandeyi & 5 & 12 & 0.042 & 2.4 & 0.13 \\
\hline Total & 31 & 116 & 0.262 & 14.1 & 0.99 \\
\hline
\end{tabular}

(Table 2). The over all prevalence (2.97), intensity (32.8) and abundance (11.3) were also calculated and presented in Table 2.

Table 3 shows the prevalence, intensity and abundance of helminth parasites in five length group of the host fish M. armatus. The highest prevalence, intensity and abundance was recorded in length group 140- 190 while it was lowest in length group 38-88.

\section{DISCUSSION}

Maximum parasitic infection was observed in Ascaridia ganpatii (nematode) followed by Polyonchobothrium armatii (cestode) while it was minimum in Eucreadium pandeyi (trematode) in M. armatus. Similar observation has been observed by Malhotra and Chauhan (1984) in seven species of hill stream fishes viz. Barilius bendelisis, B. bola, Labeo dero, L. rohita, M . armatus, M. pancalus, Schizothorax richardsonii and S. plagiostomus.

The prevalence of parasitic infestation in M. armatus was 2.97 , intensity 32.8 and abundance 11.3 . The Maximum prevalence, intensity and abundance of infection was observed in May and ,minimum in August I, obviously indicated that maximum number of fishes harbored infection during summer period than other seasons of the year. Similar findings have been reported earlier by Reimchen (1982) in Gastrostius acul eatus by Cyathoccphalus truncates and Schistocephalus solidus infections; Rand and Burt (1985) in the fall fish Semotilus by All ocreadium Iobatum infection; Timmons et al. (1992) in cat fish Ictalurus punctatus by Acetodextra amiuri infection; Cone and Roth (1993) in O ligocottus maculosus by Gyrodactylus maculesi infection and Khanum et al. (2008) in Rita rita by Phyllodistomum folium, 0 pigaster gomti, Horatrema pristipomatis, Pseudophyllidae and Cucullanus dogieli. In Himalayan region Malhotra and Chauhan (1980) observed maximum cestode infection during summer months and minimum during rainy months in thirteen species of hill stream fishes viz. Barilius barana, B. bola, B. vagra, B. bendelisis, Garra gotyla gotyla, Glyptothorax telchitta, Heteropneustes fossilis, Labeo calbasu, L. dyocheilus, L. rohita, Schizothorax plagiostomus and S. richardsonii. Further, Malhotra et al. (1981) observed maximum nematode infection in summer and minimum in rainy months in twelve species of fishes viz. Barbus tor, B. putitora, Channa punctatus, C. striatus, Cirrhina mrigala, Garra gotyla gotyla, Glyptothorax telchitta, Heteropneustes fossilis, Mastacembalus armatus, M. pancalus, Mystus seenghala and Wallago attu.

The maximum infection was recorded in middle size range while very small and larger fishes showed lesser susceptibility to helminth parasites in the present study. This infection pattern may be due to the difference of composition of food and age immunity. The present findings supported by the observation of Singh and Malik (2004) who observed the maximum parasitic

Table 2. Monthwise prevalence, intensity and abundance of parasites in M. ar matus during the year 2008-2009.

\begin{tabular}{lcccccc}
\hline M onths & \multicolumn{2}{c}{ Total no. of fish } & $\begin{array}{c}\text { No. of } \\
\text { parasite collected }\end{array}$ & Prevalence & Intensity & A bundance \\
\cline { 2 - 6 } & Examined & Infected & & & & \\
\hline March & 10 & 4 & 15 & 0.40 & 3.8 & 1.5 \\
April & 14 & 6 & 24 & 0.43 & 4.0 & 1.7 \\
May & 9 & 5 & 29 & 0.56 & 5.8 & 3.2 \\
June & 13 & 3 & 11 & 0.23 & 3.7 & 0.9 \\
July & 11 & 1 & 2 & 0.09 & 2.0 & 0.2 \\
August & 7 & 1 & 1 & 0.14 & 1.0 & 0.1 \\
September & 10 & 2 & 7 & 0.20 & 3.5 & 0.7 \\
October & 9 & 3 & 11 & 0.33 & 3.7 & 1.2 \\
November & 14 & 3 & - & 0.21 & 1.7 & 0.4 \\
December & 8 & - & - & - & - & - \\
January & 5 & - & 11 & - & - & - \\
February & 8 & 3 & 116 & 0.38 & 3.6 & 1.4 \\
\hline Total & 118 & 31 & & 2.97 & 32.8 & 11.3 \\
\hline
\end{tabular}


Table 3. Prevalence, intensity and abundance of helminth parasites in different length groups of M . armetus during the year 20082009.

\begin{tabular}{lcccccc}
\hline $\begin{array}{l}\text { Length } \\
(\mathrm{mm})\end{array}$ & $\begin{array}{c}\text { Host } \\
\text { Examined }\end{array}$ & $\begin{array}{c}\text { Host } \\
\text { infected }\end{array}$ & $\begin{array}{c}\text { No. of } \\
\text { Parasites }\end{array}$ & Prevalence & Intensity & Abundance \\
\hline $38-88$ & 15 & 1 & 1 & 0.067 & 1.0 & 0.07 \\
$89-139$ & 24 & 6 & 16 & 0.25 & 2.5 & 0.63 \\
$140-190$ & 33 & 12 & 55 & 0.36 & 4.6 & 1.67 \\
$191-241$ & 27 & 9 & 37 & 0.33 & 4.1 & 1.37 \\
$242-284$ & 19 & 3 & 8 & 0.16 & 2.7 & 0.42 \\
\hline
\end{tabular}

infection in middle size range of Catla catla, Ophiocephalus striatus, Clarias batrachus, $\mathrm{H}$. fossilis and Trichogaster fasciatus. Similar observation has also been reported by Shomorendra et al. (2007) in different length groups of $\mathrm{C}$. gachua, $\mathrm{C}$. striatus, Clarias batrachus and Anabus testudientus. In the present study it is inferred that decreased infection in larger sized hosts may be due to strong resistance developed by the fishes

\section{ACKNOW LEDGEMENT}

The authors are thankful to the Head, Department of Zoology D.A.V. (P.G.) College Dehradun for providing the necessary facilities.

\section{REFERENCES}

Akter, M. A., Hossain, M. D. and Rahman, M. R. (2007) Parasitic diseases of exotic carp in Bangladesh. J . Agric Rural Dev., 5 (1 - 2) : 127-134.

Alam, Md. J., Rakibuzzaman and Hasan, M. M. (2010). Comparative study of endo-parasitic infestation in Channa punctatus (Bloch, 1793) collected from hatchery and sewage lagoon. Nature and Science, 8 (5) : 152-155.

Ayanda, O. I. (2008). In comparative study on the parasitic infection between the different age groups of Clarias gariepinus from the Asa dam, North-central, Nigeria. African J ournal of E nvironmental Science and Technology, 2 (11): 404-406.

Cone, D. K. and Roth, H. (1993). Prevalence and intensity of Gyrodactylus maculesi sp.n. (Monogenea) parasitizing gill of sculpin (Oligocottus maculosus), in coastal British Columbia Canada. J. Helm. Soc. Wash., 60 (1) : 1-4

Fagerholm, H. P. (1982). Parasites of fish in Finland. VI, Nmatodes. Acta Academiae Aboensis. Ser. B., 40 (6) : 1-128.

Jha, A. N. and Sinha, P. (1990). The occurance of helminth parasites in relation to size of fish. Bio J ournal, 2 (11): 311 316.

Khan, M. N., Aziz, F., Afzal, M., Rab, A., Sahar, L., Ali, R. and Naqvi, M. (2003). Parasitic infestation in different fresh water fishes of Mini Dams of Potohar Region, Pakistan. Pakistan J ournal of Biological Sciences, 6 (13) : 1092-1095.

Khanum, H, Ferdows, J. and Farhana, R. (2008). Community of helminth parasites in Rita rita (Hamilton Buchanun). J. Biosci., 16: 133-135.

Malhotra, S. K. and Chauhan, R.S. (1980). Statistical analysis of cestode infection in relation to some ecological aspects of hill-stream fishes in Garhwal Himalayas, India. Indian J ournal of Helminthology, 32,(1): 43-52.
Malhotra, S. K. and Chauhan, R. S. (1984). Helminth infection in hill-stream fishes. Indian J our nal of Parasitology, 8 (2) : 303-305.

Malhotra, S. K., Chauhan, R.S. and Kapoor, V. N. (1981). Statistical analysis of nematode infection in relation to some ecological aspects of hill-stream fishes in Garhwal Himalayas, India. J . Environ Res., II, I : 18-28.

Margolis, L., Esch, G. W., Holmes, J. C., Kuris, A. M. and Schad, G. A. (1982). The use of ecological terms in parasitology (Report of the American Society of Parasitologists). J ournal of Parasitology, 68 :131-133.

Moyo, D. Z., Chimbira, Ch. and Yalala, Ph. (2009). Observations on the helminth parasites of fish in Insukamini Dam, Zimbabwe. Research J ournal of Agriculture and Biological Sciences, 5 (5) : 782-785.

Ozer, A. O. and Ozturk, M. O. (2004). Prevalence and intensity of G yrodactylus arcuatus Bychowsky, 1933 (Monogenea) infestations on the three-spined Stickleback, Gasterosteus aculeatus L., 1758. Turk J. Vet Anim Sci., 28 : 807-812.

Rand, T. G. and Burt, M. D. B. (1985). Seasonal occurrence, recruitment and maturation of Allocreadium lobatum Wallin, 1909 (Digenea : Allocreadidae) in the fall fish Semotilus corporalis Mitchell in a new Brunswick, Canada Lake system. Can. J. Zool., 63 (3) : 612-616.

Reimchen, T.E. (1982). Incidence and intensity $C$ yathoccphalus truncates and Schistocephalus solidus infection in $\mathrm{G}$ astrostius aculeatus. Can. J. Zool., 60 (5) : 1091-1095.

Shomorendra, M., Jha, A.N. and Kumar, P. (2005). Seasonal occurrence of helminth parasites in fishes of Loktak Lake, Manipur. Uttar Pradesh J. Zool., 25 (1) : 23-27.

Shomorendra, M. Jha, A. N. and Kumar, P. (2007). Effect of length of fish on the occurrence of helminth parasites. U ttar Pradesh J. Zool., 27(1) : 87-91.

Singh, A.R. (2006). Preliminary observation of seasonal influence in prevalence, mean intensity and relative density of flukes in fresh water fish, Clarias batrachus (Linn.) in relation to trematode infestation. Proc. Zool. Soc. India, 5 (1) : 31-34.

Singh, Om V. and Malik, B. S. (2004). Helminth infection in some fresh water food fishes. Him. J. Env. Zool., 18 (2) : 113-116.

Tasawar, Z., M. Arshad and M. Akhter, (2007). Observations on Lernaeid parasites of catla catla from a fish hatchery in Muzaffargarh, Pakistan. Pakistan Vet. J ., 27(1): 17-19.

Timmons.T.J.,Schuler,R.J.JR. and Dubinis-Gray, L.F. (1992). Prevalence of Acetodextra amiuri (Trematoda: Cryptogonimidae) in channel cat fish I ctalurus punctatus from Kentucky lake, Kentucky-Tennessee. J. HIminthol. 
Soc Wash., 59 (1) : 147-148.

Woo, P.T.K. (1995). Fish diseases and disorders. Ist Edn., Vol. 1. Protozoan and metazoan infections. C A B International, UK : 808 .

Yamaguti, S. (1959). Systema H elminthum. 2. The C estode of Vertebrates. Interscience Publishers. New York, pp. 769.

Yamaguti, S. (1961). Systema helminthum. The nematodes of vertebrates. Interscience Publishers. New York and London, Vol. III, Part I - II, 1-1261.

Yamaguti, S. (1971). Synopsis of digenetic trematodes of vertebrates. Keigaku publishing Co.,Tokio, 1:107.

Zaman, Z. Leong, T. S. and Hamida, K. A. (1986). Effects of length (equal age) of Clarias on the abundance of parasites. Bangladesh J. Zool., 14 (2) : 171-178. 